\title{
ICT AS ONE OF THE TEACHING METHODS AT PRIMARY SCHOOL FROM A TEACHER'S POINT OF VIEW
}

\author{
PROBLEMS \\ OF EDUCATION \\ IN THE $21^{\text {st }}$ CENTURY \\ Volume 61,2014
}

\author{
Martin Skutil \\ University of Hradec Králové, Czech Republic \\ E-mail: martin.skutil@uhk.cz
}

\begin{abstract}
ICT is one of the driving elements of the current primary education. They often replace commonly used teaching methods, however, in many cases, they are also rejected as an element of eliminating the human factor in education. Based on a qualitative survey, the paper presents an interactive whiteboard as a teaching element from the perspective of primary education teachers. The main goal of the research is to point out the teachers' inner motives to use modern technologies in education and identify the broader context of a teachers' preparation with regard to the use of IT in school practice. The research is conducted using semi-structured interviews; the method of constant comparison was used for the qualitative data analysis. The most important findings show that teachers perceive information technology, especially as activating and motivating factor in education. Another important feature is the possibility of immediate and quick scan of the results. For most respondents, it is a replacement for traditional teaching resources, while they don't forget to mention the importance of printed materials.
\end{abstract}

Key words: ICT in education, interview with teachers, primary education, teaching methods.

\section{Introduction}

ICT has recently gained a groundswell of interest. It is a significant research area for many scholars around the globe. Their nature has highly changed the face of education over the last few decades. In most European countries, the use of ICT in education and training has become a priority during the last decade. However, very few have achieved progress. Indeed, a small percentage of schools in some countries achieved high levels of effective use of ICT to support and change the teaching and learning process in many subject areas. Others are still in the early phase of ICT adoption (Advantages of Using ICT, 2014).

\section{Problem of Research}

The naturalness of a child and especially a child of a younger age is the controlling of things by his hand. Small children touch things and they intuitively manipulate them with their fingers. Opposite to all other didactic tools, interactive whiteboard automatically provides feedback, whether the task was fulfilled correctly or not. Interactive whiteboards are designed to engage a wide variety of students in the learning process. They evolved from constructivist pedagogy and support each of the three principles of universal design for learning. The product provides teachers with multiple ways to represent information using interactive text, images, sound and video files, and thus engage a broad range of learners (Smart, 2009).

A number of research investigations were realised concerning the discussed topic. It could be mentioned, e.g. (Smart, 2006), who described, that interactive whiteboard supports mutual communication and helps students to apply in class new cultural and language elements. This and results of other researches showed that if interactive whiteboard is currently used, it further improves the process of learning. Latham's (2002) observation brought cognition that 
PROBLEMS

OF EDUCATION

IN THE $21^{\text {st }}$ CENTURY

Volume 61,2014

106

work with interactive whiteboard brings strategies suitable for the development of interactive teaching. Coxat et al. (2003) in the conclusions of the report, beside others, introduces, that interactive whiteboard helps towards a deeper understanding of students, who are able to learn better and cooperate with others. The British Educational Comilvermunications and technologies Association (BECTA), which supports research aimed at the exploitation of interactive whiteboard in education in primary school, financed the project, in which took part together with the teachers in the first level of primary schools. According to them, attention and interest of the students increase during the lessons, where an interactive whiteboard was used (Bidaki \&Mobasheri (2013). Students are as "glued", they concentrate during the time of learning and obtain more pieces of information. Vanderlinde, Aesaert \& van Braak (2014) focused on Institutionalised ICT use in primary education. Special attention is paid to widely accepted technology uses by teachers, which is labelled as 'Institutionalised ICT use'.

The fact that student engagement directly affects teaching and student motivation to learn has been well documented. In an action research study conducted by William D. Beeland, Jr. (2002), he set out to determine and document the effect of the use of interactive whiteboards as an instructional tool on student engagement.

Within the modern teaching facilities, we commonly encounter working with a computer. For primary education, we use computers with a variety of educational programs. Other representatives of modern information technologies are the Internet and mobile phone (Maněnová Skutil, 2009). Primary school children commonly use both.

\section{Research Focus}

In the broadest sense, the didactic means are all understood as material resources (such as real objects, phenomena, visual aids, board, etc.) and intangible (e.g. methods, organisational forms of teaching, etc.) natures, which contribute to the overall effectiveness of the teaching process (Götz, Häffner, 2004). Dhiman (2008) sees the educational resources as objects and phenomena to achieve established goals. The means in a broader sense include everything that leads to the fulfilment of educational objectives, compared with (Yan, 2009).

Kalhous and Obst in Maněnová (2009) reported that "the function of didactic material means stems from the fact that a person gains $80 \%$ of the information visually, $12 \%$ of the information audibly, $5 \%$ of the information by touch and $3 \%$ by other senses.

According mentioned above, the main goal of the research is to point out the teachers' inner motives to use modern technologies in education and identify the broader context of a teachers' preparation with regard to the use of IT in school practice.

\section{Methodology of Research}

\section{General Background of Research}

At the beginning of this research, there were several fundamental questions that relate to the current discussion regarding the use of information and communication technologies in education. Are interactive whiteboards really such a great asset in teaching at primary schools so it is worthy to invest considerably in their purchase and maintenance? Is the great expansion of this technical didactic means adequate to what it enriches and enlivens in teaching? Can an interactive whiteboard be the reason why children change their minds towards schools and begin to look forward to lessons? What are the teachers' views regarding the use of interactive whiteboards in teaching? Is the operation of the board and preparation for each subject so complex and time consuming that they prefer to leave its advantages in the background of their traditional teaching methods?

With regard to the posed questions, the most appropriate approach to exploration seems to be qualitative methodology that helps us to understand the nature of the phenomenon. 
Sample of Research

The selection of appropriate respondents was designed in such a way that there are teachers represented who work on the widest range of primary schools, i.e. at fully organised school as well as small schools. It was followed not only the opinions of teachers in different age groups, but also with differing lengths of practice. In total, the interviews were conducted with eight respondents. Respondents are between 28 and 46 years of age with 12 years average practice.

\section{Instrument and Procedures}

A semi-structured interview was used as the research method. The respondents were not informed in advance about the specific issues used in the interview. The only information they had was the subject of "interactive whiteboard", for this reason the respondents did not have the opportunity to prepare answers to the questions in advance and therefore they answered naturally and immediately. All conducted interviews were recorded on tape. The responses were then re-written while the non-verbal reactions of the respondents were also recorded (Silverman, 2013). To maintain anonymity, only first names of the respondents were used, and the primary schools, in which the respondents operate, were not identified in the transcripts of the interviews.

\section{Data Analysis}

The analysis and processing of the data obtained used a constant comparison method, which is based on the constant comparison of the responses obtained in the interviews, searching for differences and similarities or matches (Švaříček, Šed'ová, 2007). This method is suitable for the analysis of the selected research and most closely matches the intent to compare respondents' answers and therefore create a more general opinion on the question.

\section{Limitation of the study and Ethical principles}

Like in any qualitative study, we can also find limitations in this one that arise from the nature of the research survey. The biggest drawback is of course the personality of the statements. Although there were efforts to select a representative sample of respondents, their testimonies projected personal involvement in working with ICT as well as a comprehensiveinnovative approach to education, which belongs to the group of teachers. Another element entering the testimonies of the respondents can be seen in the approach of school management, which is certainly reflected in the total approach of the respondents. The impossibility to generalise the results to a broader population of teachers is also seen as a limitation, although the data obtained provide an interesting basis for further, possibly quantitative study.

The ethical aspect has already been outlined above. However, it is worth recalling that, with regard to the possible identification of respondents, only the first names of the respondents were used, and the primary schools in which the respondents operate were not indicated in the transcripts of the interviews.

\section{Research Results}

By obtaining an interactive whiteboard (or whiteboards) among the school inventory basically everything begins. As with any didactic resource, also, the deployment of an interactive whiteboard has its advantages and disadvantages. 
Martin SKUTIL. ICT as One of the Teaching Methods at Primary School from a Teacher's Point of View

PROBLEMS

OF EDUCATION

IN THE $21^{\text {st }}$ CENTURY

Volume 61,2014

108

I guess it's a good tool for practicing. It has a large range, wide index, plenty of exercises. It's kind of a reservoir of exercises to practice in a variety of styles, in a colourful way. As an advantage I see that kids like it. Their eyes always shine up when working with a whiteboard. They look forward to that a lot. (Iveta)

I think that it has benefits especially for children, because it enhances the lessons, kids love it. They like to work with the board, even if they only write something there with the felt-tip and it is not therefore entirely interactive. But otherwise a benefit for me? (Thinking) The advantage is that children are entertained. It is also usually fast work, when you think about it. (Lenka)

The advantage is, like, when it is installed the same way as I have it. I have it on the other side of the classroom, so it can really be separated. I can prepare a program or training exercises for them, whereby they work on the board themselves. So they manage longer entirely without my help and I can have a look to see how they worked. Then, what I have already said, a demonstration of everything, faster access to data, which I use when I need to show something or explain. Also to scan workbooks when I show the children where we are, on the board they can see it straight away. (Martina)

When considering the disadvantages of interactive whiteboards, it is clear that the disadvantages presented by individual respondents can be quite a subjective opinion, which may be influenced by the overall opinion on this technique - if a teacher literally "prayed" to have an interactive whiteboard in the classroom, then they are not going to search any shortcomings or disadvantages. In contrast, a teacher who quietly suffers the presence of a whiteboard in the classroom can see the entire series of drawbacks and disadvantages.

The big disadvantage is that only one pupil at a time can work on it. So when I compare it, one board is black and this board is white. But more students at a time can work on a blackboard. Oh, and another disadvantage is that sometimes it doesn't work well. One of my colleagues has a lot of problems with it. It doesn't work, it needs fixing all the time, they cannot figure out why it doesn't work. And also if the internet doesn't work, nothing works. So when you have a prepared presentation, then it is no good. And another disadvantage is that children don't talk much when by the board. I try to work on it and improve it, but the board does not exactly develop this point well. Yeah, and actually another disadvantage is that everything is installed or modified by some administrator, so sometimes we wait a while. (Marcela)

According to me it also takes an extremely long time. What I would normally say to children in a few seconds and they understood, because it is not essential information. And yet it happens sometimes that there is, for example a technical problem, for example, that a child cannot move the indicator well. Eventually, it unnecessarily diverts attention from what was actually aiming to convey. The benefit is generally very small, but the time which it flushes is huge. (Milan)

The interactive whiteboard is undoubtedly a modern didactic tool that combines more computer possibilities and presentation technology, multimedia content and Internet in one device. When combining these technologies, the interactive whiteboard becomes a cornucopia of possibilities and applications. Therefore, what specific traditional teaching aids can the interactive whiteboard replace?

Well, it certainly replaces the pictures. For example, when I teach the national symbols, I do not have to bring the flag, poster. It certainly replaces the visual material. And also I played them spoken word in English, so that we can have the so-called English for kids, so the language beautifully well heard. So it replaces a CD player or cassette recorder. (Marcela)

Other didactic. (Thinking, a long silent pause) Well, it does replace some. Not fully, but I can always find something with which the board can help. For example, I think it can fully replace the 
minerals and things like that. Yeah, when I don't have them, I can show them, but it is better to examine them, when they can touch them. I can play them some examples, so I don't need to have

players and TV, yeah that's true. (Martina)

Yet, there may be situations where some teaching aids cannot be replaced by modern technology.

(Laughing, thinking) I don't think the board will replace books. I just think that the book, the book cannot be replaced. The kind of feeling that I can hold and read a book, I have privacy for it, the intimacy. Well, the technique drags children away from reading. A book is simply essential, it must not be extinguished! (The final words were said emphatically) (Iveta)

... but what I can touch, will never be replaced by the board. (Martina)

Interactive whiteboards are therefore definitely not smooth, like every other technology, but with its wide range of applications, they will definitely not only find a place in every school, but also in any school subjects. How often do teachers use interactive whiteboards as a means for teaching their students?

Well, mostly in Czech language, sometimes in mathematics, although lately not so much. Sometimes in biology, we also had traffic education which was nice, it was also fun. Well, how often? Sometimes I use it every day for the whole week, sometimes I don't use it all week. (Laughs) Just how it suits me, as I have it prepared for the subject. (Lenka)

We use the board every day. And in which subjects? Maths, Natural Science, partly Music, Czech. In other subjects, for example for demonstrations. I also use tutorials that I have. (Martina)

I do not use it too often unnecessarily. Today the curriculum is so acquired, we must run madly. And as I said, the board can be a big help, but on the other hand, also a terrible delayer. (Laughs) (Milan)

In order to assess the real contribution of this technology into teaching, it is necessary to know what the actual opinions of the pupils themselves are as the recipients of information from a teacher towards using an interactive whiteboard in a classroom. Given that the current generation of children has much closer relationship to computing and electronics than their parents, we can assume that also the work with interactive whiteboards will be more fun for children opposed to the "common" interpretation of a teacher, no matter how hard they try. Therefore, from the perspective of children, is working with interactive whiteboards a favourite activity?

Yes, it is. They love working with it. When they can move something and things like that, they are happy. But it is more of a reward for them, because they don't have it often. (Zuzana)

Well, certainly they like it. Especially those who do not see it so often. As soon as they can move something, shift something, they are happy. (Hana)

Students can not only act as recipients of information, but on the other hand, through interactive whiteboards they can also give teachers feedback on how they managed to understand the subject matter. The opinion of the respondent, who as the only male represented teachers, may seem interesting. He noted that children like the board, but he viewed the popularity from a somewhat different angle: 
PROBLEMS

OF EDUCATION

IN THE $21^{\text {st }}$ CENTURY

Volume 61,2014

110
Yeah, definitely. As I said, they just see that it resides. They know that it is a respite as they walk to the board... Then the tasks made by female teachers are mostly so trivial, simple primitive, predictable in advance. (Smile) And moreover, when someone makes a mistake, they will hear a sound, they know they have made a mistake, so they just drag the point to the other and correct. So I think that it is a big relief for children. Therefore, they prefer to do dragging type of exercises and so on. They simply don't have to sweat so much (laughs). (Milan)

\section{Discussion}

The results of the research survey are basically in agreement with other studies dealing with a similar topic. It shows that teachers generally perceive ICT as a positive element in education in primary schools. The present findings are consistent with, for example, S. Wastiau et al. (2013), who analysed the use of ICT in education from the perspective of selected European countries and show a positive connectedness between the focus on digital support of education and the positive approach to ICT for teachers in these schools.

The interactive whiteboard is seen as an element that makes it possible to provide information and instructions to pupils in an interesting and effective way. Here, the findings are in compliance with De Smedt \& Van Keer (2014), who state that to maximise writing performances, ICT needs to be integrated with instructional practices combining strategy instruction and collaborative writing.

De Witte \& Rogge (2014) deal with the efficiency of ICT in education in their paper. They show an example of mathematics that using the 2011 'Trends in International Mathematics and Science Study' (TIMSS) data, we define by a Mahalanobis matching a control group with similar student, teacher, school and regional characteristics. The results indicate that accounting or not accounting for these characteristics may considerably alter the estimated impact of ICT. This is confirmed with the observations of our respondents.

As indicated by Lim \& Oakley (2013), it needs to be acknowledged, that having ICT in the primary curriculum and classroom does not guarantee enhanced learning, and may represent little more than the new means of reaching pre-existing, and perhaps inappropriate or outdated, ends. Furthermore, ICT in education needs to be supported by appropriate policies at all levels and effective professional development for teachers. These observations practically correspond with the ideas of the respondents in our survey, who do not perceive ICT as a panacea element, but as a tool, which needs a foothold in educational politics and especially in teachers.

It is clear that the discussion of qualitative research's results is always associated with the limits arising from the qualitative survey nature. However, it turns out that the subjective opinions of Czech teachers in principle correspond with the results of similar researches. It also shows that ICT is perceived by teachers as a positive element in primary education, although they retain a certain distance with respect to the irreplaceability of interpersonal communication.

\section{Conclusions}

Interactive whiteboards have already become an integral part of the equipment of classrooms, even in the smaller schools, and constitute an important element in teaching. My previous statement is related to the adequacy of the boom of interactive whiteboards, which was caused by wide support from the European Union and the general need to deploy computing in school education, which can be found today in almost any area of human activity.

Teachers themselves view the use of interactive whiteboards from several angles. One of them brings them positive in the form of a large diversification of teaching, the introduction of new advanced features using multimedia content, and of course, making learning more attractive for students. Another angle puts additional responsibilities on teachers, the need for thorough preparation regarding the creation of digital teaching materials co-operating with interac- 
tive whiteboards, as well as creating backup procedures in case of technical problems. Every teacher is an individual person and it is only up to them to what extent an interactive board will supplement their interpretation, to what extent they will use it to respond to the weak points in the understanding of the subject matter, or whether it will become "a dictator" in the curriculum of the subjects and the quality of teaching will be dependent on it.

\section{Acknowledgements}

This paper was written as part of a specific research project of the Faculty of Education, University of Hradec Králové No. 2107/2014 Analysis of education process from usage of teaching methods point of view

The authors also acknowledge the support of the Ministry of Education, Science and Sport of Republic of Slovenia and European Social Fund in the frame of the Project: "Innovative pedagogy 1: 1 in the light of competences of the 21 st century" on Faculty of Natural Sciences of University of Maribor.
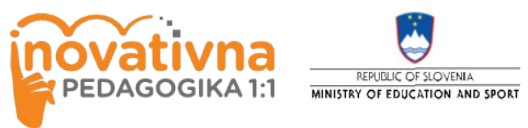

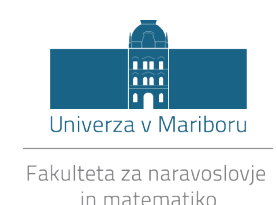

in matematiko

\section{References}

Advantages of Using ICT in Learning-Teaching Processes (2014). Retrieved March 15, 2014, from http://edtechreview.in/trends-insights/insights/959-advantages-of-using-ict-in-learning-teachingprocesses

Beeland, W. D. (2002). Student engagement, visual learning and technology: Can interactive whiteboards help? Retrieved from http://scholar.google.com/scholar?hl=en\&sourceid=navclient\&rlz= 1T4DKUS enUS299US299\&ie=UTF-8\&q=beeland

Bidaki, M. Z., \& Mobasheri, N. (2013). Teachers' views of the effects of the interactive white board (IWB)

on teaching. Procedia - Social and Behavioral Sciences, 83, 140-144. DOI: 10.1016/j. sbspro.2013.06.027

Cox, M., Webb, M., Abbott, C., Blakeley, B., Beauchamp, T., \& Rhodes, R. (2003). ICT and Pedagogy: A Review of the Research Literature. Retrieved March 10, 2014 from http://www.becta.org.uk/ page documents/research/ict_pedagogy_summary.pdf

De Smedt, F., \& Van Keer, K. (2014). A research synthesis on effective writing instruction in primary education. Procedia - Social and Behavioral Sciences, 112, 693-701. DOI: 10.1016/j. sbspro.2014.01.1219.

De Witte, K., \& Rogge, N. (2014). Does ICT matter for effectiveness and efficiency in mathematics education? Computers \& Education, 75, 173-184. DOI: 10.1016/j.compedu.2014.02.012.

Dhiman, O. P. (2008). Understanding education: An overview of education. New Delhi: Kalpaz Publications.

Goldin, C., \& Katz, L. F. (2008). The race between education and technology. Harvard University Press.

Götz, K., \& Häfner, P. (2004). Didactic Organization of Teaching and Learning process. Frankfurt am Main: Peter Lang.

Latham, P. (2002). Teaching and learning primary mathematics: The impact of interactive whiteboards. Retrieved March 10, 2014 from beam.co.uk/pdfs/RES03.pdf

Lim, Ch. P., \& Oakley, G. (2013). Information and communication technologies (ICT) in primary education. In Creating holistic technology-enhanced learning experiences. pp 1-18. SensePublishers. DOI: 10.1007/978-94-6209-086-6 1.

Maněnová et al. (2009). ICT a učitel 1. stupně základní školy [ICT and a teacher at an elementary school]. Brno: Computer Press. 
Martin SKUTIL. ICT as One of the Teaching Methods at Primary School from a Teacher's Point of View

PROBLEMS

OF EDUCATION

IN THE $21^{\text {st }}$ CENTURY

Volume 61,2014

Maněnová, M., \& Skutil, M. (2010). ICT and audiovisual technic in nurseries in the Czech Republic. In International Conference on Applied Computer Science (ACS'10). Athens: WSEAS Press.

Yan, Z. (2009). Limited knowledge and limited resources: Children's and adolescents' understanding of the Internet. Journal of Applied Developmental Psychology, 30, 103-115.

Silvermann, D. (2013). Doing qualitative research. London: Sage.

SMART Technologies (2009). Creating classrooms for everyone. Retrieved March 12, 2014 from http://downloads01.smarttech.com/media/research/whitepapers/ interactivewhiteboardsanduniversaldesignforlearningjan20.pdf

SMART Technologies (2006). Interactive whiteboards and learning: Improving student learning outcomes and streamlining lesson planning. SMART Technologies. Retrieved March 12, 2014 from http://downloads01.smarttech.com/media/education/pdf/interactivewhiteboardsandlearning.pdf

Švaříček, R., \& Šed'ová, K. (2007). Kvalitativní výzkum v pedagogických vědách [Qualitative Research in Educational Sciences]. Praha: Portál.

Vanderlinde, R., Aesaert, K., \& van Braak, J. (2014). Institutionalised ICT use in primary education: A multilevel analysis. Computers \& Education, 72, 1-10. DOI: 10.1016/j.compedu.2013.10.007

Wastiau, P., Blamire, R., Kearney, C., Quittre, V., Van de Gaer, E., \& Monseur, C. (2013). The use of ICT in education: A survey of schools in Europe. European Journal of Education, 48, 11-27. DOI:10.1111/ejed.12020

Advised by Laima Railiene, University of Šiauliai, Lithuania

Received: June 30, 2014

Accepted: August 23, 2014

Martin Skutil

PhD., Associate Professor, Institute of Primary and Pre-primary Education, Faculty of Education, University of Hradec Králové, Hradec Králové, Czech Republic. E-mail: martin.skutil@uhk.cz 